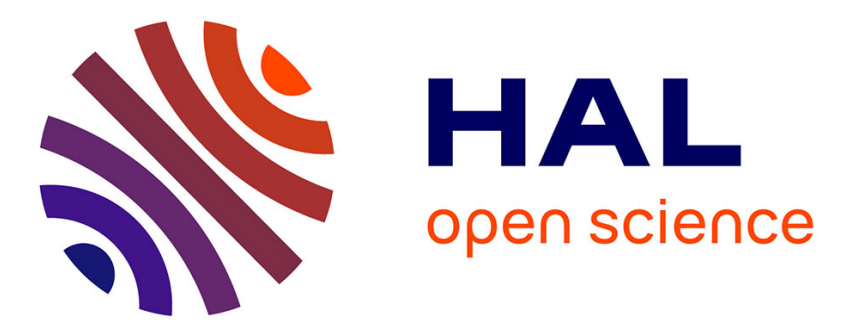

\title{
Role of VR Throughout the Life of Low Volume Products Towards Digital Extended Enterprises
}

Simo-Pekka Leino, Antti Pulkkinen, Juha-Pekka Anttila

\section{To cite this version:}

Simo-Pekka Leino, Antti Pulkkinen, Juha-Pekka Anttila. Role of VR Throughout the Life of Low Volume Products Towards Digital Extended Enterprises. 14th IFIP International Conference on Product Lifecycle Management (PLM), Jul 2017, Seville, Spain. pp.404-415, 10.1007/978-3-319-72905-3_36 . hal-01764173

\section{HAL Id: hal-01764173 \\ https://hal.inria.fr/hal-01764173}

Submitted on 11 Apr 2018

HAL is a multi-disciplinary open access archive for the deposit and dissemination of scientific research documents, whether they are published or not. The documents may come from teaching and research institutions in France or abroad, or from public or private research centers.
L'archive ouverte pluridisciplinaire HAL, est destinée au dépôt et à la diffusion de documents scientifiques de niveau recherche, publiés ou non, émanant des établissements d'enseignement et de recherche français ou étrangers, des laboratoires publics ou privés. 


\title{
Role of VR throughout the life of low volume products towards digital extended enterprises
}

\author{
Simo-Pekka Leino ${ }^{1}$, Antti Pulkkinen ${ }^{2}$, Juha-Pekka Anttila ${ }^{1}$ \\ ${ }^{1}$ VTT Technical Research Centre of Finland Ltd., Tampere, Finland \\ ${ }^{2}$ Tampere University of Technology, Tampere, Finland \\ Simo-Pekka.Leino@vtt.fi
}

\begin{abstract}
This paper discusses the role of virtual reality from the perspective of PLM, based on several industrial case studies. As a result of the research a virtual reality in PLM utilization model is proposed. The proposed model regards virtual reality value creation and prerequisites from PLM perspective. Utility of the model is discussed from business management point of view.
\end{abstract}

Keywords: Virtual Reality, Virtual Prototyping, Framework, Extended Enterprise

\section{Introduction}

Virtual Reality (VR) technology is living its renaissance, thanks to entertainment business. However VR has a great potential in industry as well, but the demands and benefits are somewhat different. Additionally real value and preconditions of VR are still often unclear in industry [1]. Simultaneously, PLM concept itself is evolving and expanding from engineering data management towards genuine innovation and business platform. Naturally, this affects the PLM architecture as well. In this context, VR should be connected to PLM model and business value.

This paper discusses the role of VR from the perspective of product lifecycle management (PLM) based on several industrial case studies. In the context of this research, VR applications and virtual environments (VE) are user friendly interfaces to product models such as virtual prototypes (VP). In other words: virtual prototyping is a methodology and process perspective, a virtual prototype is a model of the design object, VEs are the way of experiencing and interacting with the model, and VR represents the technology utilized in virtual prototyping [1]. The extended [1] concept Intermediary Virtual Prototyping (IVP) underscores the many layers and dimensions of VP from technical advantages (immersion, interac- 
tion) of VR to the expanded mediating object of product related activity system connecting VR and VP also to PLM framework. VR based VP is widely seen as an enabling technology for intensifying product processes [2]. VP techniques also facilitate better concurrent engineering [3], Kansei engineering [4] and communication among cross-functional teams. The VEs enable engineers to consider product lifecycle downstream issues earlier in the product design phase, and make design changes even in the conceptual design stage [5-6]. Nevertheless, VP could be utilized more efficiently and systematically, but according to our experiences companies are today lacking an understanding and knowledge of the real value and significance of VP (see e.g. [7]. There is a "paradox" of common statements of the high utility of VP and simultaneously a relatively low level of real adoption in industry [1].

The scientometric study of [8] concerning PLM International Conferences between 2005 and 2014 listed ten most frequent keywords of research papers. It is no surprise that not VR or VP are included in that list. In PLM2015 one or two of papers were related to the subject, and 2016 conference coverage was not remarkably bigger. Word "virtual" gives five articles, and "VR" none in a keyword search of International Journal of Product Lifecycle Management. Therefore we reasoned that VR and VP should be integrated to the body of knowledge of PLM, where this paper aims to contribute. Relative to PLM, this research aims to answer following questions: How VR applications can be categorized? Where are the main benefits of VR? What are the essential enablers of VR utilization? The rest of this paper is structured as follows: Research approach is shortly described. After that the "VR utilization framework in PLM" is introduced and discussed. Finally main conclusions are summarized.

Research method was based on industrial case studies (Table 1) including interviews, workshops, process and information modelling, and comparison of past and ongoing development projects. Nature of the case study is action research, meaning that the aim is on analyzing the present challenges and changing the situation in the company. The research approach is constructive and as a result of the research a VR in PLM utilization model is proposed. From the business perspective, companies are studied with a resource based view (see [9])

\section{Background}

In a 2016 finished Accelerate research project goal was to improve integration of engineering design and production in product development of a forest machine manufacturer. VR based VP and 3D-CAD were proposed and piloted as one means for reaching the goal. In the project ten people (see Table 1) were interviewed, and detailed result can be found in [10]. 
Table 1. Characterization of the industrial case studies

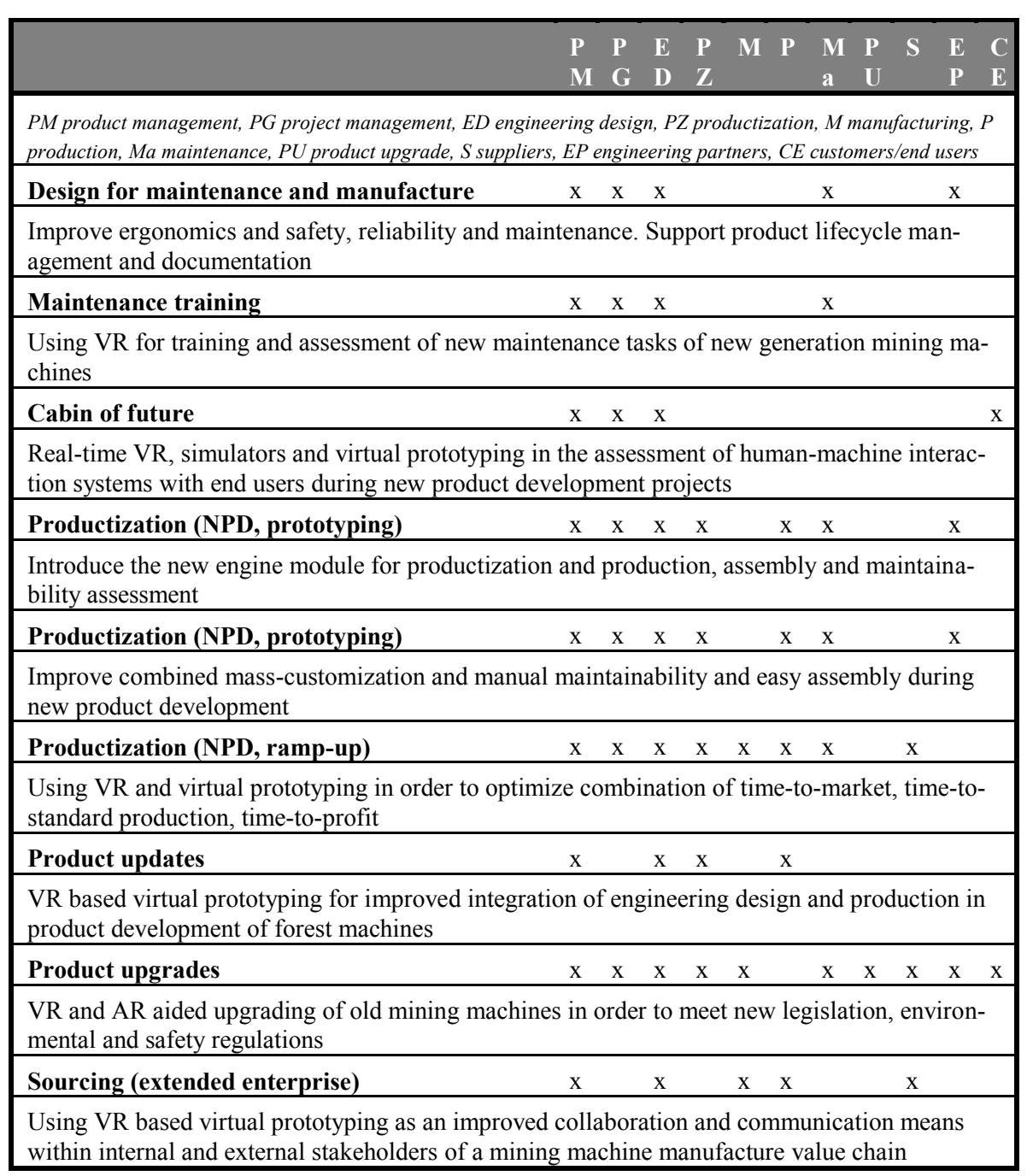

In a 2016 finished similar type of research project called Promagnet (report available ${ }^{2}$ ), fifteen mid- and senior managers from nine internal business functions (see table) of a mining machine manufacturing company were interviewed. Topic of the interviews was a past very challenging new product development project. Results and conclusions are treated in [1].

2 http://hightech.dimecc.com/system/attachments/files/000/000/053/original/DIMECC_MANU_Final_report_ebook.pdf?147947392 
Current Dexter (Digital Extended Enterprise) research project expanded stakeholders to include three manufacturing suppliers of welded sheet structures, machined parts, sub-assemblies, and modules of mobile mining machines. Aim of the project is to improve productivity by means of digital technology. The suppliers deliver parts and sub-assemblies for both standard production and prototypes. Based on interviews and workshops, improved use of 3D-models and virtual prototypes has been recognized as one of the main target areas.

In a 2016 finished EU funded FP7 research project called Use-it-Wisely aim was to establish business models and platforms that enable life-long adaptation of high investment product-services. The Finnish cluster case focused on upgrading old mining machines in order to meet new legislation, environmental and safety regulations [11]. VR and AR were selected and piloted as means for improving communications and collaboration between upgrade project stakeholders. In the tool trial phase, ten people from the mining equipment manufacturing and service company were interviewed concerning the utility of VR in upgrading projects [12].

LEFA (New Generation Human-centred Design Simulators for Life-cycleefficient Mobile Machines) project developed user-centred design methods for mobile working machines based on VR and virtual prototypes [13]. Two participating companies represented manufacturers of mining and construction machines and container handling equipment.

\section{VR Utilization Framework in PLM}

The utilization model includes five main layers (Figure 1): Digital Extended Enterprise, Processes, Tools, PLM content, and Data management. Extended enterprise is the dynamic organizational structure where VR-based product processes are executed. The product processes can be principally categorized in two dimensions as virtual (models, information flows) and physical (material flow), and product-based and service-based. The fundamental idea of using VR and VP is to create projections of the physical product processes and material flows as well as physical product based services to the virtual side.

Engineering design is traditionally transforming [14] demands of customers, users and society into requirements specifications, product concepts, embodiments designs and finally detailed design specifications in the virtual product quarter (1). In the physical product quarter, design specifications are released to sourcing, part manufacturing, and production/assembly (2). A finished product individual is shipped to a customer where it is operated, maintained and finally disposed. However, the lower section of the process layer, namely virtual (3) and physical services (4) often are vaguer and less precisely defined.

In extended enterprises product related processes such as part manufacturing, assembly, prototyping, maintenance, and product upgrades are provided as ser- 
vices. Because in extended enterprise collaboration, parallelism and information flows are essential capabilities, these services and related product properties should be designed concurrently. Therefore the virtual service section becomes very interesting from the VR in PLM perspective. The stakeholders and actors of extended enterprises participate to the virtual product-service processes with different perspectives bringing their diverse knowledge. Furthermore, based on our industrial case studies, the process layer includes four different VR utilization types: (A) New product development (NPD), (B) standard production support, (C) standard service support and product individual upgrade support (D).

\section{VR Value Creation}

Using VR and IVP, the properties and functions of physical products as well as related services and processes can be discussed and evaluated earlier, before physical manufacture and assembly. Additionally, for instance product-based services, such as maintenance work tasks can be designed before building the physical products and systems. VR enables better understanding of product models and information for unexperienced people, thus improved communication and knowledge sharing between stakeholders, decreased uncertainty, and better quality fast decision making [1], [9] [15-17]. The stakeholders can virtually test and train the use of the products, which may lead to improved usability and ergonomics [18]. The potential business impact of VR may also be derived from a more holistic view of the product-service system [3]. Generally, early prototyping should be seen as a management tool and means for learning [19]. More detailed value creation dimensions and mechanisms are discussed in [1]. There main value creation dimensions include processes, people (organization and individuals), and business management. This paper extends the value creation context to wider product lifecycle and on the other hand to extended enterprises.

In PLM, life phases of products can roughly be divided [20] into the Beginning of Life (BoL) - design and manufacture; the Middle of Life (MoL) - operation and support; and the End of Life (EoL) - retire or upgrade. This view is different from marketing, where a product life is divided into five phases: introduction, growth, maturity, saturation and degeneration [21]. The following Table 2 summarizes the value creation mechanisms during the three main product life phases.

Generally engineering change requests and modifications are made too late in NPD projects, leading to costly rework with physical prototypes. VR and design reviews allow finding design flaws early, thus engineering changes can be made before manufactured physical prototypes [1], [22]. This leads to decreased timeto-market and time-to-profit. 


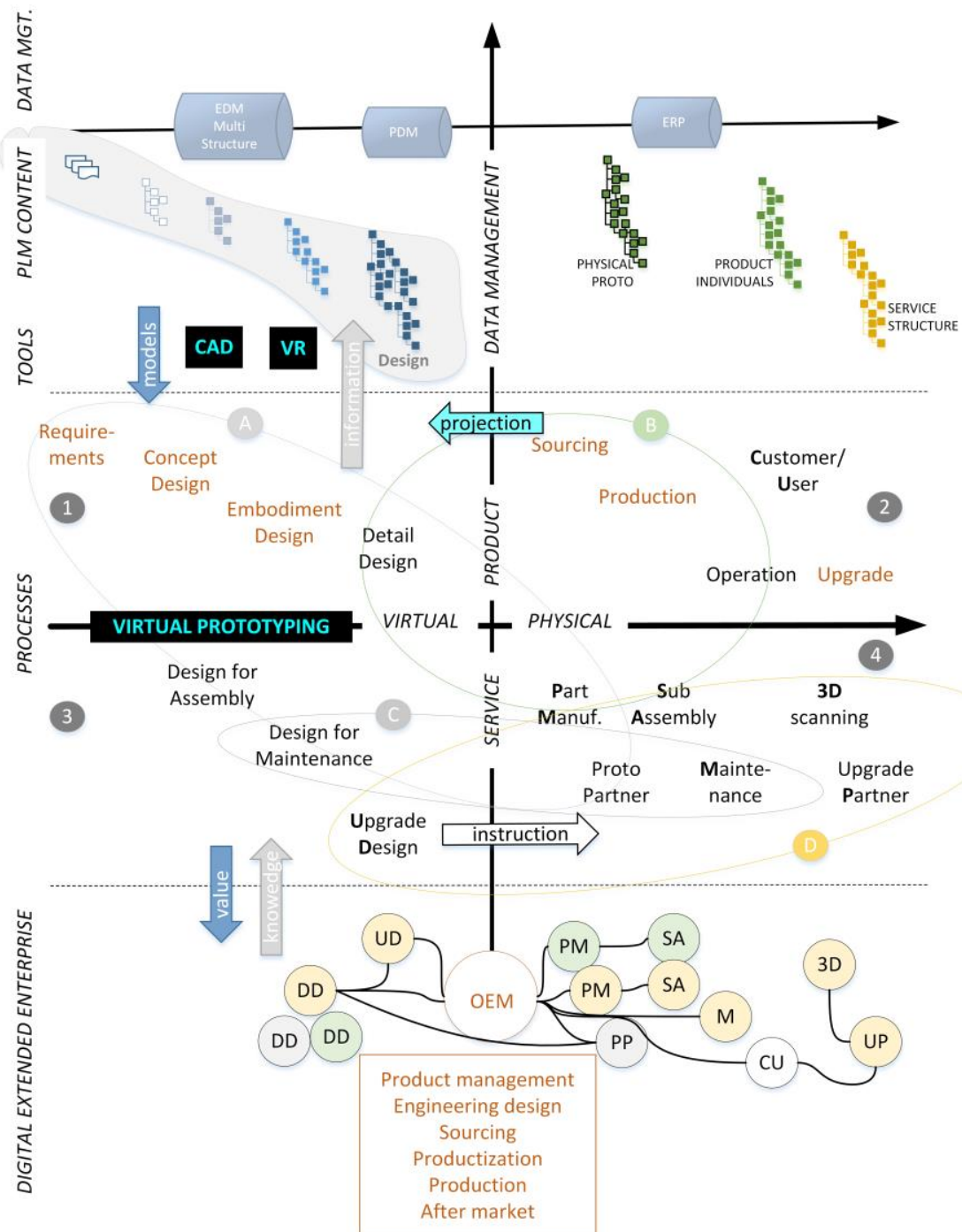

Figure 1 Visualization of the VR Utilization Framework in PLM 
Table 2 Examples of value creation mechanisms during the three main product life phases and PLM dimensions

\begin{tabular}{|c|c|c|c|}
\hline & Process & People & Business \\
\hline $\begin{array}{l}\text { New product devel- } \\
\text { opment (BoL) }\end{array}$ & $\begin{array}{l}\text { Requirements valida- } \\
\text { tion, concept design } \\
\text { and validation, de- } \\
\text { sign reviews, proto- } \\
\text { typing, marketing, } \\
\text { production ramp-up }\end{array}$ & $\begin{array}{l}\text { Communication and } \\
\text { understanding, or- } \\
\text { ganizational learning, } \\
\text { knowledge creation } \\
\text { and sharing, shared } \\
\text { mental models, re- } \\
\text { vealing contradic- } \\
\text { tions }\end{array}$ & $\begin{array}{l}\text { time-to-market, time- } \\
\text { to-serial production, } \\
\text { decreased physical } \\
\text { prototyping cost, de- } \\
\text { cision making de- } \\
\text { creased uncertainty, } \\
\text { productivity (infor- } \\
\text { mation), value-chain } \\
\text { design }\end{array}$ \\
\hline $\begin{array}{l}\text { Standard produc- } \\
\text { tion support (BoL) }\end{array}$ & $\begin{array}{l}\text { Engineering change, } \\
\text { design for assembly, } \\
\text { part manufacturing, } \\
\text { sub-assembly ser- } \\
\text { vices, knowledge } \\
\text { feedback }\end{array}$ & $\begin{array}{l}\text { Transferring skills } \\
\text { and information from } \\
\text { NPD to standard } \\
\text { production, ability to } \\
\text { improve one's work }\end{array}$ & $\begin{array}{l}\text { time-to-profit, } \\
\text { productivity (materi- } \\
\text { al), balanced perfor- } \\
\text { mance and core } \\
\text { competence, value- } \\
\text { chain optimization }\end{array}$ \\
\hline $\begin{array}{l}\text { Standard services } \\
\text { (MoL) }\end{array}$ & $\begin{array}{l}\text { Design for mainte- } \\
\text { nance, product- } \\
\text { service co-design, } \\
\text { sales and marketing }\end{array}$ & $\begin{array}{l}\text { Involvement of new } \\
\text { stakeholders, service } \\
\text { training }\end{array}$ & $\begin{array}{l}\text { Prototyping partner, } \\
\text { service innovations, }\end{array}$ \\
\hline $\begin{array}{l}\text { Upgrade support } \\
\text { (EoL) }\end{array}$ & $\begin{array}{l}\text { Upgrade design, fit- } \\
\text { ting an upgrade solu- } \\
\text { tion to an old product } \\
\text { individual, design } \\
\text { reviews, sales, illus- } \\
\text { tration of upgrade of- } \\
\text { fering, 3D-scanning }\end{array}$ & $\begin{array}{l}\text { Involvement of new } \\
\text { stakeholders, } \\
\text { knowledge capture, } \\
\text { commitment }\end{array}$ & $\begin{array}{l}\text { New upgrade busi- } \\
\text { ness models, im- } \\
\text { proved productivity } \\
\text { (information and ma- } \\
\text { terial), upgrade part- } \\
\text { ner relationships }\end{array}$ \\
\hline
\end{tabular}

When a new product is ramped-up to production, it is important to effectively transfer information and knowledge from product development to standard production, and equally important to transfer knowledge back to design engineers. This can be supported by VR and digital manufacturing approach [23]. In the middle of life, the product is operated and maintained. With the use of VR and IVP, these actions can also be designed. Product upgrades in the end of life are special types of services. Profitability of product upgrade service projects may often be questionable because the actual status of the upgrade target is not known, and communication between customers, service people, suppliers and design engineers is difficult. VR is a means to visualize scan-based and 3D-CAD models so that customer and other stakeholder requirements as well as proposed design solutions can be validated before building the physical system. Productivity is increased because unproductive rework and information search can be decreased [11]. 


\section{Preconditions for value creation}

As stated before, the benefits of virtual prototyping cannot be attained for free. Certain preconditions and pre-requisites are needed before VR and VP really create value for internal and external customers. As [24] stated, the success of VR aided design requires both technical and organizational prerequisites. Also [3] and [25] argued that "virtual engineering" cannot lead to a significant improvements when put to existing processes. [26] argued that virtual prototyping also requires "virtual confidence". In [1] these preconditions are discussed in details. The next paragraphs give a short summary of them divided to dimensions of processes, organization and technology since they are often seen as the main dimensions of PLM.

Processes implications: In the big picture, effective utilization of VR and IVP requires actually a paradigm change in engineering design and product development which are the essential processes that produce and utilize virtual product models. IVP should be understood as a pivotal process within PLM. The product process should be frontloaded so that e.g. assembly and maintainability can be analysed and improved using the virtual prototypes. Naturally, the frontloading affects how the design maturity, i.e. the $3 \mathrm{D}$ product model and structure should evolve in order to support all stakeholders.

Organizational implications: It is important to recognize and respect the internal customers both inside the company and in the extended enterprise. Thus, a culture that encourages openness, knowledge sharing and sharing unfinished models as well as constructive feedback is required. IVP should be organized in dynamic multi-disciplinary teams that are not based on the formal line organizations or company boundaries, but rather on the required knowledge of all stakeholders. On the other hand, utilization of VR in IVP creates new roles such as VR developers and design review organizers. From the financial perspective, it should be understood that VR and IVP do not belong just to a single organizational unit (e.g. engineering design), but to whole business and product lifecycle.

Technological implications: As VR and IVP are discussed here from a PLM perspective, implications to product model and data management are interesting. The above described changed and frontloaded product processes require capabilities for managing parallel product model structures. The virtual prototype structure often is different from the design structure (EBOM) and from e.g. manufacturing strucure (MBOM) since it is typically a simplified and restricted model made for a certain purpose [1]. Effective utilization of IVP also requires efficient bi-directional data flow between VR and CAD/EDM including data conversion and simplification as well as meta-data transfer. PLM should provide capabilities for giving feedback directly on the virtual prototype model and that information should be available for design engineers in their working environment i.e. CAD/EDM. A "baseline" or "as-built" model structure is proposed as a frame for information and knowledge flow as well [23], [1]. The upgrade solution of old 
product individual requires capability to transform and manage point clouds or other scanned 3D data in order to be utilized in VR, see more e.g. in [11].

\section{Discussion}

Utilization of VR and IVP can be considered as manifestations of industry digitalization. Digitalization increases transparency both internally and between companies [27], which is goal of Extended Enterprises. Term "Extended Enterprise" probably originates [28] in Chrysler Corporation where it was used for improving information exchange and decreasing cost in value chains. According [29] Extended Enterprise (EE) consists of collaborating upstream and downstream companies from raw material production even to end customers creating value to market. The EE approach requires a new organizational strategy aiming to overall optimization, deep collaboration, flexibility and change from linear and sequential process toward parallelism [30]. Practically, EE collaboration requires mechanisms that enable collaboration and communication between heterogenous organizations and systems [31]: Conceptual models, data-models, organizational structures and processes, and technical solutions like software tools. According to [28] this kind of development requires more than ad-hoc reactions to changing situations. It requires commonly accepted practices aiming to systemic and holistic knowledge management and business benefits [29]. Digitalization of EEs require recognition and analysis of relevant concepts and technologies [27].

This paper discusses how VR, IVP and PLM could possibly provide for the demanded collaboration mechanisms and systematic development of EEs. From the perspectives of problem solving and improved productivity, development of relationships between stakeholders is one of the most essential success factors [28]. Lowering the barriers between organizations and internal departments has been the goal for a long time, but in reality development has rather been towards more siloed organizations in order to simplify management in the world of ever more complicated products and complex business models [32].

The Germany based concept Industry4.0 is an example of value network digitalization including disruptive and social innovations. Concerning digitalization and Industry4.0, a key question is what kind of impacts supply chains will face in future [27]. VR has been seen as a means for effective collaboration [33]. Extended enterprise and IVP [1] as business and social concepts and VR as a piece of technology boost new innovations, because [32] they enable better communication and collaboration of people from different organizations with different backgrounds.

PLM as a Platform: Management of product lifecycle objects, collaboration between stakeholders, analysis of challenges, and making decisions are tasks of PLM [34]. Therefor VR as a technology and IVP as a methodology should be seen as part of companies' PLM models and architectures. [35] for instance has con- 
cluded that in automotive industry there is a growing demand for visual simulations which drives towards rethinking product processes and PLM.

As was reasoned before, service design is one of the major value creating processes where VR can be utilized. [36] proposed a value creation framework that could be expanded with VR. Servicization requires better integration of products and services, thus effective collaboration and digital continuity [37]. Compared to physical products, services are generally under-designed and ineffectively developed, because manufacturing companies still have a traditional engineering approach to the tangible part of engineering leaving the intangible service element to intuitive processes and methods [38], [21]. On the other hand, PLM increasingly focuses on the whole product lifecycle, both the product types and individuals, promising to manage all related data and information [21]. VR and IVP should be seen as enablers of effective product-service design when the data and processes really support them. Also [38] have discussed using VR for interaction between service providers and clients, and visualizing new service concepts.

The concept of "Closed-loop PLM" of [34] takes even greater upon the holistic product lifecycle closing the information gaps between different phases and processes of the product life both backwards and forwards [21]. This requires knowing all product lifecycle activities, how information is created, used, modified, accumulated and even utilized in the next generation products [34]. As described before, VR and IVP could help here too when integrated in PLM.

\section{Conclusion}

The proposed framework for utilization of VR includes the dimensions of product lifecycle stages, extended enterprise stakeholders and disciplines, value creation, managerial and technical implications. The framework was reflected with the industrial case studies and business benefits. From the extended enterprise perspective, VR and IVP enable improved knowledge sharing and transparency between the stakeholders. The proposed framework supports decision making and planning of VR investments in the context of PLM architecture development. This paper also contributes to research by discussing the closed-loop PLM concept, involving virtualization of product-service system development.

\section{Acknowledgements}

This research was funded and supported by Tekes, EU, Dimecc and participating organizations. 


\section{References}

[1] Leino, S.-P. (2015). Reframing the value of virtual prototyping Intermediary virtual prototyping - the evolving approach of virtual environments based virtual prototyping in the context of new product development and low volume production. Tampere University of Technology. http://www.vtt.fi/inf/pdf/science/2015/S89.pdf

[2] Leino, S.-P., \& Riitahuhta, A. (2012). State of the art of virtual engineering based humanmachine system lifecycle knowledge transfer and management. In Proceedings of TMCE 2012, May 7-11, 2012, Karlsruhe, Germany (pp. 573-586).

[3] Ovtcharova, J. G. (2010). virtual engineering : principles, methods and applications. in international design conference - DESIGN 2010 (pp. 1267-1274).

[4] Arrighi, P., Maurya, S., \& Mougenot, C. (n.d.). Towards Co-designing with Users : A Mixed Reality Tool for Kansei Engineering. In IFIP International Conference on Product Lifecycle Management. Springer International Publishing.

[5] Cecil, J., \& Kanchanapiboon, A. (2007). Virtual engineering approaches in product and process design. The International Journal of Advanced Manufacturing Technology, 31(9-10).

[6] Seth, A., Vance, J. M., \& Oliver, J. H. (2011). Virtual reality for assembly methods prototyping: a review. Virtual Reality, 15(1), 5-20.

[7] Aromaa, S., Leino, S., Viitaniemi, J., Jokinen, L., \& Kiviranta, S. (2012). Benefits of the use of virtual environments in product design review meeting (pp. 355-364).

[8] Bhatt, S., Tseng, F. H., Maranzana, N., \& Segonds, F. (2015). Scientometric Study of Product Lifecycle Management International Conferences: A Decade Overview. In IFIP International Conference on Product Lifecycle Management (pp. 1-8). Springer International Publishing.

[9] Leino, S.-P., Koivisto, T., \& Riitahuhta, A. (2013). value of virtual prototyping - a strategic resource based view. In Proceedings of the 19th International Conference on Engineering Design (ICED 13) (pp. 249-261).

[10]Videnoja, J. (2016). Implementation of virtual prototyping in the context of product update projects and low volume production. Tampere University of Technology.

[11] Leino, S.-P., Aromaa, S., \& Helin, K. (2017). Rock crusher upgrade business from a PLM perspective. In S. Grösser, A. Reyes-Lecuona, \& G. Granholm (Eds.), Dynamics of LongLife Assets. Springer.

[12 ]Aromaa, S., \& Väänänen, K. (2016). Suitability of virtual prototypes to support human factors / ergonomics evaluation during the design. Applied Ergonomics, 56, 11-18.

[13] Aromaa, S., Leino, S.-P., \& Viitaniemi, J. (2013). Are companies ready for the revolution in design - modelling maturity for virtual prototyping. In International Conference on Engineering Design, ICED13.

[14] Hubka, V., \& Eder, E. (1988). Theory of Technical Systems: a Total Concept Theory for Engineering Design. Springer-Verlag.

[15] Gomes de Sá, A., \& Zachmann, G. (1999). Virtual reality as a tool for verification of assembly and maintenance processes. Computers and Graphics, 23, 389-403.

[16] Lindskog, E., Berglund, J., Vallhagen, J., \& Johansson, B. (2013). Visualization support for virtual redesign of manufacturing systems. Procedia CIRP, 7, 419-424.

[17] Leino, S.-P., \& Pulkkinen, A. (2012). Design for human - virtual engineering is a media for knowledge transfer. In Proceedings of DESIGN 2012, the 12th International Design Conference (pp. 1507-1514).

[18] Ottosson, S. (2002). Virtual reality in the product development process. Journal of Engineering Design, 13(January), 159-172.823

[19] Golovatchev, J., \& Schepurek, S. (2015). Early Prototyping in the Digital Industry : A Management Framework. In IFIP International Conference on Product Lifecycle Management. Springer International Publishing.

[20] Wiesner, S., Freitag, M., Westphal, I., \& Thoben, K. (2015). Interactions between Service and Product Lifecycle Management. Procedia CIRP, 30, 36-41. 
[21] Wuest, T., Wellsandt, S., \& Thoben, K. (2015). Information Quality in PLM : A production process perspective. In FIP International Conference on Product Lifecycle Management. Springer International Publishing.

[22] Di Gironimo, G., Lanzotti, A., \& Tarallo, A. (2014). A virtual reality framework for the design review of complex industrial assemblies : Case study on the interiors of superjet 100 aircraft. In I. Horváth \& Z. Rusak (Eds.), Proceedings of TMCE 2014, May 19-23, 2014, Budapest, Hungary (pp. 1553-1560).

[23] Leino, S., Jokinen, L., Anttila, J., \& Pulkkinen, A. (2016). Case study on Engineering Change Management and Digital Manufacturing. In IFIP International Conference on Product Lifecycle Management (pp. 1-10). Springer International Publishing.

[24] Zimmermann, P. (2008). Virtual Reality Aided Design: A Survey of the Use of VR in Automotive Industry. In D. Talaba \& A. Amditis (Eds.), Product Engineering - Tools and Methods based on Virtual Reality (pp. 277-296). Springer.

[25] Damgrave, R. G. J., Lutters, E., \& Drukker, J. W. (2014). Rationalizing virtual reality based on manufacturing paradigms. Procedia CIRP, 21, 264-269.

[26] Oscarsson, J., Jeusfeld, M. A., \& Jenefeldt, A. (2015). Towards Virtual Confidence - Extended Product Lifecycle Management. In IFIP International Conference on Product Lifecycle Management. Springer International Publishing.

[27] Pfohl, H., Yahsi, B., \& Kurnaz, T. (2015). The Impact of Industry y 4 . 0 on the Supply Chain. In Hamburg International Conference of Logistics (HICL).

[28] Post, J. E., Preston, L. E., \& Parker, M. (2002). Managing the extended enterprise: The new stakeholder view. California Management Review, 45(I), 6-28.

[29] Spekman, R. E., \& Davis, E. W. (2004). Risky business : expanding the discussion on risk and the extended enterprise. International Journal of Physical Distribution \& Logistics Management, 34(5), 414-433.

[30] Belkadi, F., \& Bernard, A. (2015). Trust-based patterns for the management of interenterprises collaborations in context of extended enterprise. In IFAC-PapersOnLine (pp. 1186-1191).

[31] Chen, D., \& Vernadat, F. (2004). Standards on enterprise integration and engineering state of the art Standards on enterprise integration and engineering - state of the art. International Journal of Computer Integrated Manufacturing, 17(3), 235-253.

[32] Kane, G. C., Palmer, D., Phillips, A. N., Kiron, D., \& Buckley, N. (2015). Strategy, not Technology, Drives Digital Transformation. Becoming a digitally mature enterprise. MITSloan Management Review.

[33] Brettel, M., Friederichsen, N., Keller, M., \& Rosenberg, M. (2014). How Virtualization , Decentralization and Network Building Change the Manufacturing Landscape : An Industry 4.0 Perspective. International Journal of Mechanical, Aerospace, Industrial and Mechatronics Engineering, 8(1), 37-44.

[34] Jun, H., Kiritsis, D., \& Xirouchakis, P. (2007). Research issues on closed-loop PLM. Computers in Industry, 58, 855-868.

[35] Rehfeld, I. (2010). Virtual Reality as an Integral Part of Product Lifecycle Management ( PLM ). In Joint Virtual Reality Conference of EGVE-ICAT - EuroVR.

[36]Wang, P. P., Ming, X. G., \& Zheng, M. K. (2015). A Framework of Value Creation for Industrial Product-Service. In FIP International Conference on Product Lifecycle Management. Springer International Publishing.

[37] Mahut, F., Bricogne, M., Daaboul, J., \& Eynard, B. (2015). Servicization of Product Lifecycle Management : towards Service Lifecycle Management. In IFIP International Conference on Product Lifecycle Management. Springer International Publishing.

[38] Cavalieri, S., \& Pezzotta, G. (2012). Product - Service Systems Engineering: State of the art and research challenges. Computers in Industry, 63(4), 278-288. 